\title{
Zin en onzin van een strijdblad
}

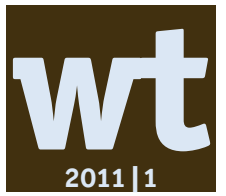

Wie in de loop van 2011 zesenzeventig jaar wordt, heeft nog steeds - en misschien vooral - recht op een mooi nieuw pak. Het zoveelste in de rij, maar toch altijd weer gericht op een vernieuwingsgedachte.

Wetenschappelijke tijdingen heeft die achtenswaardige leeftijd bereikt maar blijft ambitieus en wil ijverig verder groeien. Op het inhoudelijk vlak verloopt zo'n streven natuurlijk evolutief en procesmatig. Op het vormelijk vlak verloopt het dan weer in sprongen. Mocht die laatste term niet beladen zijn ${ }^{1}$, dan zouden wij vandaag de presentatie van de nieuwe vormgeving van ons tijdschrift inderdaad als een (nieuwe) sprong voorwaarts kunnen beschouwen. Die zin voor vernieuwing vormt een noodzaak op zich. Maar die zingeving vormt bovendien een actief onderdeel van de kennisverwerving. Wij mogen inderdaad niet zo zelfverzekerd zijn dat wij, een beetje inert en onoplettend, plaatsnemen in de stevige zetel die onze founding fathers tijdens de voorbije decennia hebben neergezet.

Toen Jozef Goossenaerts (1882-1963) in 1935 het intellectuele avontuur van Wetenschappelijke tijdingen ondernam, had hij beslist een punt. De Vlamingen bezaten dan wel sinds enkele jaren hun eigen Nederlandstalige universiteit, maar de vernederlandsing van de wetenschap had wel nog een heel eind te lopen. Zij had daarenboven schaduwen te verdrijven die niet de minste waren. Bijvoorbeeld die van de Belgische kardinaal-aartsbisschop Désiré Mercier (1851-1926). Over die bekende grootwaardigheidsbekleder mogen de Vlaamsgezinden dan al ijverig hun mythes hebben verspreid en gekoesterd, 's mans overtuiging dat "het Nederlands nooit een volwaardige cultuurtaal kon zijn" lijkt een vaststaand feit ${ }^{2}$ en die controversiële overtuiging was beslist geen bagatel in de context van toen.

Zonder stuwkracht - zeg maar zonder strijd - zou de beweging van Goossenaerts en zijn geestesgenoten mogelijk zijn gestrand in haar eigen onmacht.

1. Een verwijzing naar de Grote Sprong Voorwaarts (1958-1960) van de Chinese leider Mao Zedong (1893-1976).

2. R. Boudens \& L. Gevers, Mercier, Désiré J., in: Nieuwe Encyclopedie van de Vlaamse Beweging (NEVB), Tielt, 1998, p. 2035. 
Maar de wisselwerking tussen hun Vlaamse Wetenschappelijke Congressen, hun Vereniging voor wetenschap en hun wetenschapsbevorderend persorgaan Wetenschap in Vlaanderen - later Wetenschappelijke tijdingen genoemd - werkte. Die synergie en dat strijdende karakter bleven elkaar onverminderd motiveren, decennia lang. Net zolang tot de doelstellingen feitelijk achterhaald werden door een nieuwe synergie, nl. die van de institutionele ontwikkelingen en de explosieve groei van de Vlaamse universitaire en academische wereld. Toen verdween voor Wetenschappelijke tijdingen de nood aan de promotie van de wetenschapsbevordering in algemene zin. Daarom werd van 1980-1981 af gekozen voor een specifieke focus in de wetenschapsbeoefening: de geschiedenis van de Vlaamse beweging. ${ }^{3}$ Tegelijk verdween stilaan elke politieke kleuring, die voordien weliswaar niet intentioneel was bepaald maar die wel behoorde tot de logica van het strijdbare engagement. De uitbreiding van de redactie naar het pluriforme academische veld, de verbreding van de inhoudelijke focus op de geschiedenis van de Vlaamse beweging en ten slotte de 'internationalisering' van de historiografische inzichten, vormden definitief de ruggengraat van het evoluerende redactiebeleid.

Wat ooit startte als een strijdblad inzake de wetenschap is dat eigenlijk ook gebleven. Zij het in een geheel andere zin, namelijk als de zoektocht naar het breedst mogelijke weten en het meest open inzicht met betrekking tot de geschiedenis van de Vlaamse beweging. Al bezit het begrip 'strijd' natuurlijk niet in alle omstandigheden dezelfde connotatie.

In onderhavig $W t$-nr. 2011,1 biedt Jos Monballyu verder zijn onderzoeksresultaten aan m.b.t. de repressie van de Vlaamse activisten ${ }^{4}$ na de Eerste Wereldoorlog. Voor dat onderzoek steunt de auteur zich op wat hij "de bron bij uitstek" noemt om die repressie te beschrijven, namelijk de gerechtelijke archieven van de instellingen die de repressie verrichten. In zijn onderhavige bijdrage stelt hij vast dat de maand april van 1919 "een drukke vervolgingsmaand" was voor de Krijgsraad van het Groot Hoofdkwartier van het Belgisch leger. Die instelling was tijdens de Eerste Wereldoorlog opgericht ter versterking van de zogenaamde krijgsradente-velde; zij oordeelde in de loop van 1919 over honderden personen - burgers en militairen - die werden verdacht van activisme. Enkele honderden onder hen werden effectief vervolgd.

3. Tegelijk werd de titel van het tijdschrift gewijzigd in Wetenschappelijke tijdingen op het gebied van de geschiedenis van de Vlaamse beweging. Van het werkjaar 2006 af werden op de omslag Wetenschappelijke tijdingen én het letterwoord Wt gebruikt. De eerste eigenlijke bladzijde bleef verder de volledige titel vermelden.

4. In zijn vorige bijdrage stelde de auteur dat er ook 'Waalse activisten' bestonden, vermits er ook Walen waren die hadden deelgenomen aan de hervorming van de Belgische instellingen met medewerking van de Duitse bezetter. 
Als besluit van zijn twee bijdragen rondom dit thema, ontwikkelt en onderbouwt Jos Monballyu de stelling dat tijdens de eerste maanden van 1919 uitsluitend 'de kleine garnalen' van het activisme achterbleven in dit gerechtelijk repressienet van het Groot Hoofdkwartier. "De grote vissen kwamen pas vanaf september 1919 voor de hoven van Assisen" besluit hij.

Dat vele Vlaams-nationalisten personele of organisatorische, occasionele of langdurige verbindingen onderhielden met de Duitse bezetter is een algemeen bekend en vrij ruim bestudeerd historisch gegeven. Maar desondanks blijft ditzelfde gegeven een spraakmakend onderzoeksgebied. In het vorige $W t$-nummer ontwikkelde Etienne Verhoeyen in dat kader de casus van de 'Sondergruppe Student', een studiegroep die werd opgezet ter voorbereiding van de Duitse bezetting van België en die de medewerking genoot van een aantal Vlaams-nationalisten. Aan dat (voordien nauwelijks bekende en bestudeerde) facet van de collaboratie voegt Verhoeyen in het thans voorliggende $W t$-nummer een studie toe omtrent een andere, eveneens vrij cryptisch episode, waaruit blijkt "dat er een merkwaardige continuïteit [bestond] in de steunverlening vanuit Duitsland voor Vlaams-nationalistische organisaties sinds de jaren dertig van de vorige eeuw, over de oorlogsjaren heen en tot het bittere einde". Het betreft hier de geheime zendingen die na september 1944 naar Vlaanderen werden uitgestuurd en die, zoals blijkt uit de studie van Verhoeyen, 'roekeloos, onuitvoerbaar en onuitgevoerd' waren.

Het leek wel een zoveelste schimmenspel waarin het vNv (Vlaams Nationaal Verbond), de DeVlag en de Duitse bezetter met elkaar verstrikt geraakten, tijdens een aflopende wereldoorlog die voor hen maar niet kon eindigen.

Afgezien van de eigen, immanente fricties rondom een Vlaamse dan wel een Groot-Nederlandse bestemming, bevonden de Vlaams-nationalisten zich tijdens het interbellum in een politiek spanningsveld tussen de Belgische en de Nederlandse opinievorming. Vooral in Nederland was die opinievorming duidelijk gecontamineerd door de afloop van de Eerste Wereldoorlog (de mogelijke Belgische annexatie van Nederlands Limburg en Zeeuws-Vlaanderen, de discussie over het beheer van de Westerschelde enz.). Voor de Nederlandse diplomatie betekende die toestand onder meer dat zij geïnformeerd wilde zijn omtrent de perceptie die - omtrent de Belgisch-Nederlandse verhoudingen - leefde in België en in de andere Europese landen. Die bezorgdheid leidde er onder meer toe dat de in Londen docerende historicus Pieter Geyl (1887-1966) ter plekke een feitelijk informatieopdracht ontving. In Brussel fungeerde zijnerzijds de letterkundige en journalist Hendrik van der Wal (1874-1937) als "letterkundige en chroniqueur" die "daardoor de gelegenheid [zou hebben om] zonder verdacht te worden zoo ruim mogelijk aanraking te zoeken met alle Belgische kringen". 
Pieter Geyl, van wie bekend is dat hij reeds vóór de Eerste Wereldoorlog betrokken was bij de Vlaamse en Groot-Nederlandse beweging en Hendrik van der Wal onderhielden blijkbaar vriendschappelijke contacten met elkaar. De Nederlandse historicus Pieter van Hees oordeelde daarom dat het relevant zou zijn om de 'Belgische' bevindingen van Geyl en Van der Wal naast elkaar te leggen. Hij doet dat in zijn bronnenartikel Twee vertegenwoordigers (Pieter Geyl en Hendrik van der Wal) van het Nationaal Bureau voor Documentatie over Nederland berichten in juni 1922 over de Belgisch-Vlaamse politieke verhoudingen. Centraal staat daarin beider briefwisseling uit 1922.

In Vlaanderen/België gold het ambitieuze maar pragmatische flamingantisme van de katholieke politicus Frans Van Cauwelaert (1880-1961) als de pendant van de radicale stroming van de Vlaams-nationalisten. In de hierboven besproken bronnenbijdrage van Pieter van Hees lezen wij overigens hoe Pieter Geyl, op basis van zijn contacten met die Vlaams-nationalisten, rapporteerde omtrent "de halfh[ei]d van Van Cauwelaert c.s.".

Dat Frans Van Cauwelaert een zeer grote bijdrage heeft geleverd in de ontwikkeling van de Vlaamse beweging tijdens het interbellum, werd duidelijk aangetoond door de Leuvense historicus Lode Wils en de talrijke publicaties die Wils wijdde aan die katholieke voorman. Omdat die vooraanstaande figuur vijftig jaar geleden overleed, acht de historicus het betekenisvol om opnieuw aandacht te besteden aan een van de belangrijkste politieke instrumenten van Van Cauwelaert, namelijk de Katholieke Vlaamse Landsbond. Het onderzoek naar die instelling ontving daarenboven nog een sterk impuls door het recentelijk bekend worden van de - voorheen verloren gewaande - dagboeken van de Landsbond.

Begrijpelijkerwijze vormen die dagboeken het kerngegeven voor Wils' nieuwe onderzoek en zijn publicatie De Katholieke Vlaamse Landsbond.

FRANS-JOS VERDOODT | REDACTIESECRETARIS WT 